\title{
APLIKASI ANALISIS KEANDALAN PADA KEKUATAN PELAT FLOATING \\ STORAGE OFFLOADING (FSO) DENGAN MEMAKAI \\ SIMULASI MONTE CARLO
}

Vivian Karim Ladesi, ST.

\begin{abstract}
Abstrak
Analisis keandalan akhir-akhir ini semakin banyak yang menggunakanya seiring dengan perkembangan ilmu pengetahuan dan teknologi. Bukan saja diaplikasikan pada bidang statistik yang menjadi induknya tetapi juga diberbagai bidang terutama pada analisis struktur yang erat hubungannya dengan peramalan dan analisa resiko. Floating Storage Offloading (FSO) merupakan struktur terapung di lautan seperti kapal tanker yang berfungsi untuk melakukan bongkar muat minyak. Dengan keberadaan FSO di lingkungan laut di mana tingkat ketidak pastian yang begitu tinggi maka analisis keandalan merupakan faktor penting yang seharusnya dilakukan. Dengan bantuan metode simulasi Monte Carlo maka analisis ini dapat dilakuan. Analisa Monte Carlo akan memberikan hasil yang dapat dijadikan rekomendasi dalam menganalisa kekuatan FSO. Metodologi yang dipakai untuk melakukan analisa ini adalah mengumpulkan data, menetapkan ambang batas keselamatan, menentukan karasteristik peubah dasar, dan kemudian melakukan simulasi Monte Carlo. Dengan demikian maka sesungguhnya analisis keandalan ini dapat diterapkan pada tahap-tahap perancangan dan perencanaan FOS atau kapal-kapal lain.
\end{abstract}

Kata kunci : Keandalan, Floating Storage Offloading (FSO), Monte Carlo

\section{Pendahuluan}

Analisis keandalan merupakan metode baru yang digunakan dalam desain suatu struktur, di mana metode ini sangat erat hubunganya dengan data-data statistik. Dengan parameter tertentu seperti rata-rata $(\mu)$ Standar deviasi $(\rho)$ dan Koefisien Fariasi (COV) dan beberapa pararameter statistik 
tambahan yang akan membantu dalam analisis keandalan nantinya.

Floating Storage Offloading (FSO) merupakan salah satu fasilitas dalam produksi minyak lepas pantai, yang berfungsi untuk menampung minyak yang dihasilkan oleh bangunan lepas pantai. FSO merupakan jenis kapal yang mengangkut fluida dalam hal ini minyak, yang salah satu jenisnya adalah kapal Tanker yang dianggap perlu untuk mencari keandalannya.

Selama ini dalam sebuah perancangan bangunan laut dilakukan dengan cara yang konservatif. Cara ini memang cukup mudah karena untuk keamanan bangunan kita hanya perlu memberikan faktor beban dan faktor kekuatan dan selanjutnya dilakukan proses perancangan sebagaimana mestinya dengan aturan yang ada seperti pada kapal memakai rules ABS, DnV dan lain-lain. Masalahnya adalah perancangan yang digunakan belum memperhitungkan faktor ketidakpastian yang terjadi baik pada tahap perancangan sampai operasional di lapangan, seperti ketidakpastian material bahan, ketidakpastian pengukuran, ketidakpastian beban-beban dan lain-lain yang dialami oleh bangunan tersebut, dalam hal ini kapal Tanker.

Simulasi Monte Carlo biasanya digunakan untuk persoalan-persoalan yang menyangkut perubah-perubah acak yang telah diketahui atau diasumsikan distribusi peluangnya. Penyusun memakai metode dengan simulasi Monte Carlo karena beberapa alasan utama, pertama karena variabel yang cukup banyak, kedua persamaan matematis yang dimiliki oleh persamaannya cukup kompleks.

\section{Tujuan}

1. Melihat kemungkinan penggunaan analisis keandalan dalam struktur FSO

2. Menentukan metodologi yang dilakukan untuk upaya melakukan analisa keandalan pada FOS

3. Dapat menjadi salah satu metode dalam tahap perencanaan pembangunan FSO

\footnotetext{
Aplikasi Analisis Keandalan Pada Kekuatan Pelat Floating Storage Offloading (FSO) Dengan Memakai Simulasi Monte Carlo (Vivian Karim Ladesi, Dosen Jurusan Teknik Sipil FT-UNJ)
} 


\section{Pembahasan}

Dalam dua dasawarsa terakhir ini telah dikembangkan teknik-teknik probabilistik dalam rangka menilai aspek keamanan sebuah sistem rekayasa struktur, sebagai perluasan teknik yang sama yang diterapkan pada sistemsistem elektronika. Kajian perintisan dibidang ini untuk sistem struktur bahkan telah dimulai oleh Fundamental pada tahun 1950-an. Teknik-teknik probabilistik memberi pijakan yang lebih rasional mengenai tingkat keamanan sistem yang sebelumnya diakomodasikan oleh pendekatan angka keamanan. Pendekatan angka keamanan hanyalah mencerminkan ketidaktahuan kita tentang bagaimana mengkuantifikasikan ketidakpastian yang melekat pada parameter-parameter beban, kekuatan dan model yang melukiskan sistem yang ditinjau. Pendekatan probabilistik juga mulai banyak diterapkan untuk sistem struktur kapal untuk meninjau tingkat keamanannya.

Penelitian atas tingkat keselamatan atau resiko pada sistem-sistem struktur dapat dilakukan dengan teknik-teknik yang khusus dikembangkan untuk sistem struktur. Teknik analisis keandalan struktur yang banyak dipakai serta memberi hasil yang cukup akurat adalah teknik Simulasi Montecarlo.

Untuk menghitung Analisis Keandalan maka terlebih dahulu melakukan analisa pendukung seperti :

\section{Perhitungan Kekuatan Midship FSO/Tanker}

Perhitungan kekuatan kapal tanker pada midship dilakukan dengan menggunakan rule ABS (American Bureau Of Shipping) yang memberikan beberapa persamaan untuk kondisi gelombang air tenang, gelombang kondisi Sagging dan Hogging yang masing-masing persamaannya sebagai berikut:

1. Momen Kondisi Air Tenang $\left(\mathrm{M}_{\mathrm{sw}}\right)$

Momen ini terjadi akibat dari keberadaan kapal pada air tenang yang pada dasarnya terjadi kerena berat dari struktur kapal itu sendiri di mana ABS memberikannya dengan

MENARA, JURNAL TEKNIK SIPIL VOL. I, NO. 1, JANUARI 2006: 6-18 


$$
\mathrm{M}_{\mathrm{sw}}=C_{\mathrm{st}} \mathrm{L}^{2.5} \mathrm{~B}\left(\mathrm{C}_{\mathrm{b}}+0.5\right)
$$

Dimana:

$\mathrm{L}=\quad=$ Panjang kapal (Length between ) perpendiculer)

B = Lebar kapal

$\mathrm{C}_{\mathrm{b}} \quad=$ Koefisien blok

$\mathrm{C}_{\text {st }} \quad=$ Koefisien momen bending air tenang sebagai fungsi panjang kapal

2. Momen Bending Kondisi Hogging $\left(M_{w h}\right)$

Momen ini terjadi akibat beban gelombang yang terjadi pada kapal di mana puncak gelombang berada di kedua sisi ujung kapal tanker.

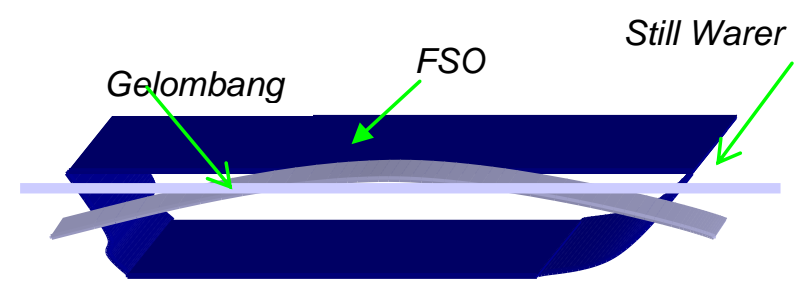

Gambar 1: Kondisi Gelombang Hogging Yang Terjadi

Persamaannya adalah :

$\mathrm{M}_{\mathrm{w}} \quad=\mathrm{C}_{2} \mathrm{~L}^{2} \mathrm{BH} \mathrm{K}_{\mathrm{b}}$

Dimana:

$\mathrm{C}_{2} \quad=$ koefisien momen bending gelombang akibat bentuk kapal

$\mathrm{K}_{\mathrm{b}} \quad=$ Koefisien funggsi $\mathrm{C}_{\mathrm{b}}$

$\mathrm{H} \quad=$ Tinggi gelombang

$\mathrm{C}_{2}=\left[2.34 C_{b}+0.2\right] 10^{-2}$

3. Momen bending kondisi sagging $\left(M_{w s}\right)$

Pada kondisi ini beban gelombang yang terjadi sama dengan hogging di mana yang yang membedakan adalah jika $M_{w h}$ Positif (+) maka $M_{w s}$ negatif (-). Kondisi gelombang yang terjadi seperti ditunjukkan pada gambar no 2 berikut:

Aplikasi Analisis Keandalan Pada Kekuatan Pelat Floating Storage Offloading (FSO) Dengan Memakai Simulasi Monte Carlo (Vivian Karim Ladesi, Dosen Jurusan Teknik Sipil FT-UNJ) 


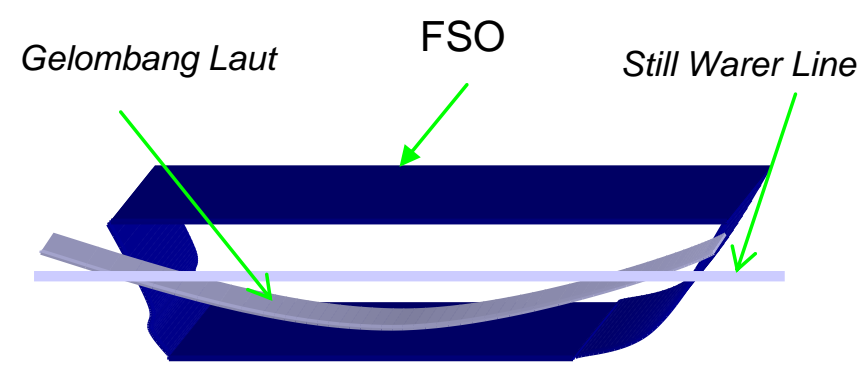

Gambar 2: Kondisi Gelombang Sagging Yang Terjadi

\section{Konsep Dasar Tegangan Pada Balok}

Tegangan lentur pada tiap titik sebuah irisan balok diberikan oleh persamaan:

$$
\sigma=\text { My } / \text { I }
$$

Tegangan paling besar untuk irisan yang sama dapat diperoleh dari hubungan diatas dengan mengambil harga lyl maksimum, sehingga akan mendapatkan persamaan:

$$
\sigma_{\max }=M c / I
$$

Pada kasus-kasus praktis maka tegangan maksimum yang diperoleh pada persamaan di atas adalah besaran yang dicari; jadi ini diperlukan sekali untuk membuat pengolahan penentuan harga $\sigma_{\max }$ menjadi sesederhana mungkin. I/c merupakan modulus irisan elastis (elastic section modulus) dari suatu irisan yang dilambangkan dengan $S$, dengan notasi ini maka persamaannya menjadi:

$$
\sigma_{\max }=\mathrm{Mc} / \mathrm{I}=\frac{M}{\frac{I}{c}}=\frac{M}{S}
$$

dimana:

$\mathrm{M}=$ Momen lentur

I = Momen inersia bentuk penampang balok

$\mathrm{C}$ = Jarak sumbu netral dengan tegangan tegangan normal

$\mathrm{S}=$ Modulus irisan elastis 


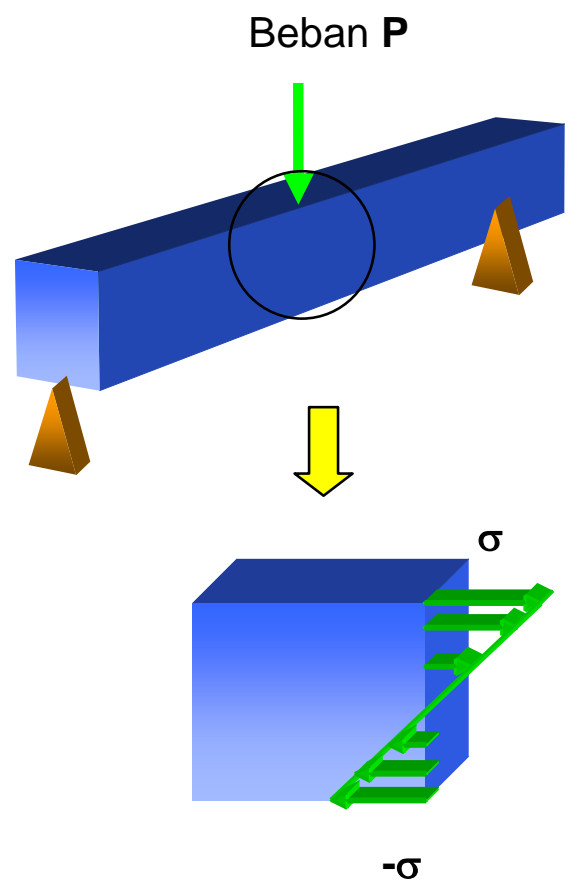

Gambar 3: Contoh Tegangan Yang Terjadi Pada Balok

\section{Tegangan Tekuk Pada Pelat FSO}

Kita misalkan bahwa tepi-tepi memanjang pelat adalah terjepit sedemikian rupa sehingga tepi-tepi ini tidak dapat berputar. Dengan mengambil lajut elemen, serta menandai momen lentur persatuan panjang yang bekerja pada tepi-tepi memanjang pelat, maka gaya-gaya yang berkerja pada lajur itu akan seperti yang diperlihatkan pada gambar 4. Momen lentur pada setiap penampang melintang dari jalur tetsebut adalah:

$M=(q l / 2) x-(q / 2) x^{2}-S w$

Bila kita mensupsitusikan ke persamaan kurva lendutan dimana

$$
\mathrm{D} \frac{d^{2} w}{d x^{2}}=M
$$

Maka menjadi: $\frac{d^{2} w}{d x^{2}}-\frac{S}{D} w=-\frac{q l x}{2 D}+\frac{q x^{2}}{2 D}$

Di mana $\quad \mathrm{D}=\frac{E t^{3}}{12\left(1-v^{2}\right)}$

Seperti pada kasus kolom yang mengalami tekuk, kekuatan pelat yang 
mengalami tekan pada bidang pelat dikaji dengan mempertimbangakan sebuah tegangan kritis, yaitu tegangan tekan tertinggi pada bidang pelat yang semula rata yang dapat menimbulkan lendutan di luar bidang bukan nol di tengah pelat. Pada tegangan di bawah tegangan kritis, pelat tersebut dapat dibebani dalam arah panjang pelat, namun tidak terjadi lendutan di luar bidang bukan nol.
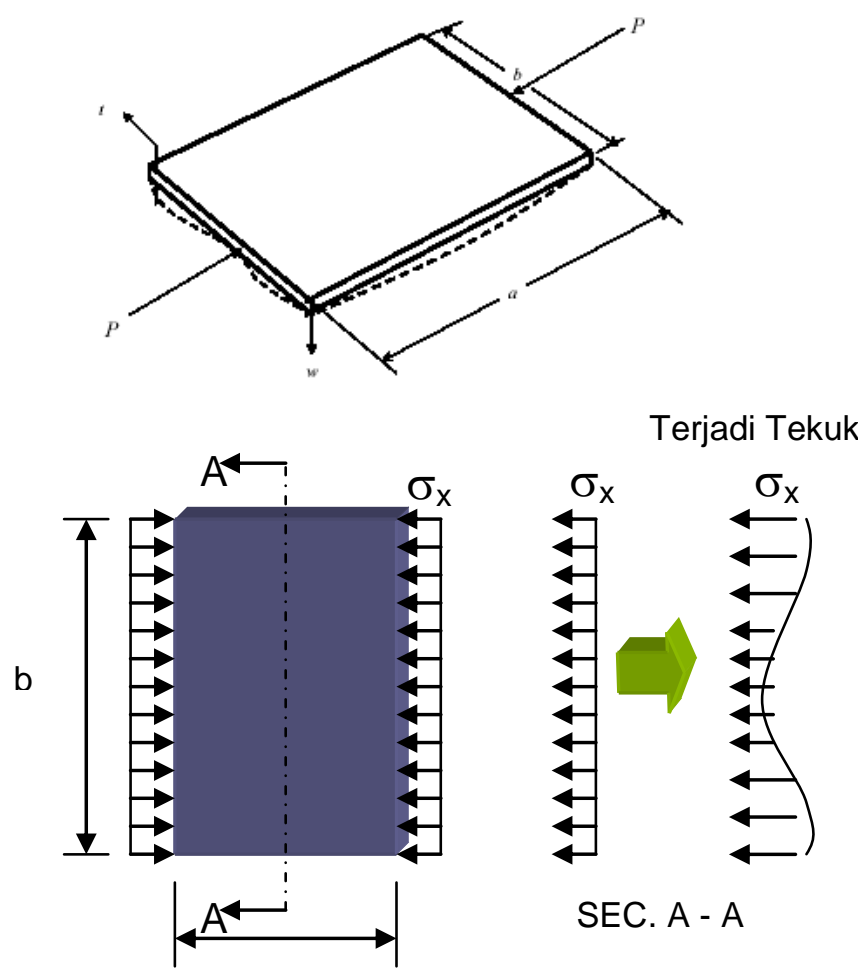

Gambar 4: Pelat Yang Mengalami Tekuk Elestis adalah:

Persamaan untuk tegangan tekuk elastis denga tumpuan sederhana

$$
\sigma_{\mathrm{xE}} \quad=\mathbf{k}_{\mathrm{c}} \frac{E \pi^{2}}{12\left(1-v^{2}\right)}\left[\frac{t}{b}\right]^{2}
$$

di sini $k_{c}$ merupakan fungsi dari aspek rasio $\alpha$, kondisi batas tepi pelat, dan jenis pembebanan. Harga-harga $\mathrm{k}_{\mathrm{c}}$ telah dihitung untuk beberapa kasus praktis yang penting.

MENARA, JURNAL TEKNIK SIPIL VOL. I, NO. 1, JANUARI 2006: 6-18 


\section{Tekanan Air Pada Permukaan Pelat}

Tekanan pada pelat yang diakibatkan oleh tekanan air laut pada bagian bawah merupakan salah satu faktor yang cukup signifikan pengeruhnya pada kekuatan dari pelat yang terletak pada bagian bawah kapal atau Bottom Stell, kerena pada bagian ini mendapat gaya tekan keatas dari air laut yang membuat pelat mengalami tegangan tambahan yang bukan hanya karena gaya memanjang kapal akibat gelombang saja.

Barikut akan diberikan ilustrasi bagaimana tekanan akibat berat kapal tersebut mengalami pembebanan;

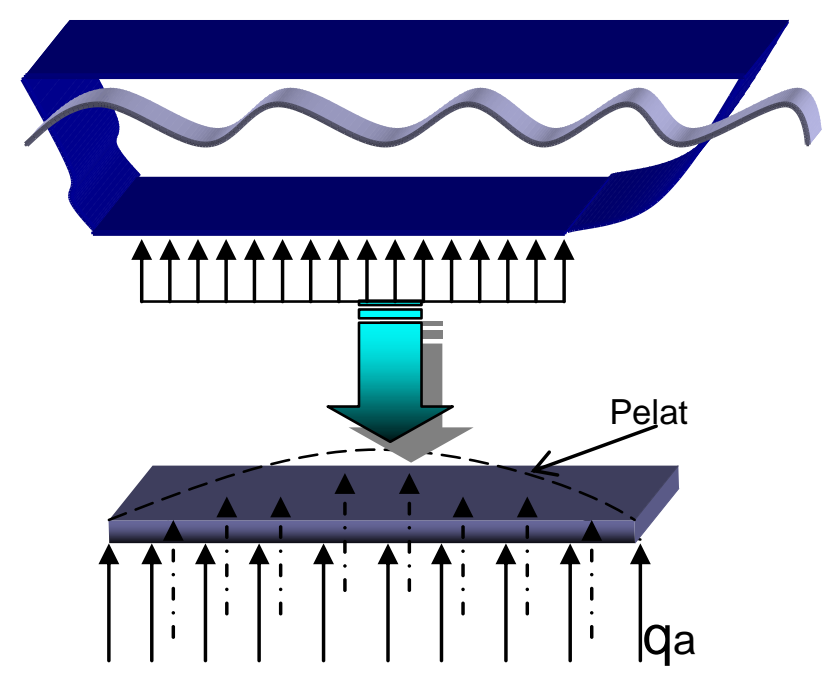

Gambar 5: Gaya Tekan Keatas Akibat Tekanan Air

Dari penggambaran tersebut maka terlihat bagaimana kinerja dari gaya tersebut berpengaruh terhadap kekuatan pelat yang ada.

Persamaan matematis yang dapat diambil untuk mendefenisikan sebarapa besar pengaruh gara tersebut adalah :

Gaya dalam $(m)=c_{2} p_{o} a^{2}$

Di mana $c_{2}$ adalah koefisien dari bentuk dari pelat dan lendutan pelat, $p_{\circ}$ adalah gaya tekan ke atas dari air laut, dan a adalah panjang pelat. Untuk nilai $\mathrm{C}_{2}$ dapat dilihat pada lampiran.

Dengan demikian tegangan yang dialami oleh pelat dapat dihitung dengan menggunakan persamaan:

$\sigma$ plat $=\mathrm{m} / \mathrm{A}$

dimana $A$ adalah luas penampang dari pelat

Aplikasi Analisis Keandalan Pada Kekuatan Pelat Floating Storage Offloading (FSO) Dengan Memakai Simulasi Monte Carlo (Vivian Karim Ladesi, Dosen Jurusan Teknik Sipil FT-UNJ) 
Pada kondisi ini hanya tekanan air laut saja yang diperhitungkan karena FSO merupakan Tanker jenis Dobell Bottom (Pelat Dobel) di mana hal ini dipakai untuk keamanan FSO tersebut dari kebocoran dan lain-lain.

\section{Simulasi Dan Metode Monte Carlo}

Unsur pokok yang diperlukan di dalam simulasi Monte Carlo adalah sebuah random number generator (RNG). Hal ini karena, secara teknis, prinsip dasar metode simultan Monte Carlo sebenarnya adalah sampling numerik dengan bantuan RNG, di mana simulasi dilakukan dengan mengambil beberapa sampel dari perubah acak berdasarkan distribusi peluang perubah acak tersebut. Ini berarti, Simulasi Monte Carlo mensyaratkan bahwa distribusi peluang dari perubah acak yang terlibat di dalam sistem yang sedang dipelajari telah diketahui atau dapat diasumsikan. Sampel yang telah diambil tersebut dipakai sebagai masukan ke dalam persamaan fungsi kinerja $\mathrm{FK}(\mathrm{x})$, dan harga $\mathrm{FK}(\mathrm{x})$ kemudian dihitung. Untuk suatu fungsi kinerja tertentu, misalnya, setiap kali $\mathrm{FK}(\mathrm{x})<0$, maka sistem/komponen yang ditinjau dianggap gagal. Jika jumlah sampel tersebut adalah $\mathrm{N}$ (atau replikasi sejumlah $\mathrm{N}$ ), maka dapat dicatat kejadian $\mathrm{FK}(\mathrm{x})<0$ sejumlah $\mathrm{n}$ kali. Dengan demikian, peluang kegagalan sistem/komponen yang sedang ditinjau adalah rasio antara jumlah kejadian gagal dengan sampel atau replikasi, $P_{g}=n / N$.

Persoalan utama di dalam simulasi Monte Carlo adalah bagaimana mentranformasikan angka acak yang dikeluarkan oleh random number generator (RNG) menjadi besaran fisis yang sesuai dengan fungsi kerapatan peluang ( $f k p)$-nya. Ini disebabkan karena angka acak yang dikeluarkan oleh RNG memiliki fkp uniform, sedangkan perubah dasar dalam $\mathrm{FK}(\mathrm{x})$ seringkali tidak demikian (misal terdistribusi secara normal, lognormal, dan sebagainya). RNG biasanya ada dalam CPU komputer sebagai built-in computer program dalam bagian ROM-nya. RNG yang disediakan ini hampir selalu berbentuk linear congruential generator yang mengeluarkan suatu deretan bilangan cacah (integer) $I_{1}, I_{2}, I_{3}, \ldots$, masing-masing antara 0 dan $m-1$ ( $m$ sebuah bilangan yang besar sekali) dengan menggunaan sebuah relasi rekurens berikut:

MENARA, JURNAL TEKNIK SIPIL VOL. I, NO. 1, JANUARI 2006: 6-18 


$$
I_{j+1}=a I_{j}+c(\bmod m)
$$

di mana $m$ disebut modulus, dan a serta $c$ adalah bilangan cacah (integer) yang berturut-turut disebut sebagai pengganda dan inkremen. Relasi rekuens di atas akan berulang dengan periode yang lebih kecil dari $m$. Jika $m$, a, c, dipilih secara seksama, maka periode ulang yang terjadi akan memiliki panjang maksimum, yaitu $m$. Dalam hal itu, semua bilangan cacah (integer) antara 0 dan $m-1$ akan muncul, sehingga setiap pilihan "biji $\mathrm{I}_{0}$ " akan menghasilkan deret yang secara statistik sama baiknya.

\section{Metodologi yang Dipakai}

1. Perhitungan Data Yang Dihasilkan

Setelah data diperoleh maka dilakukan perhitungan-perhitingan yang diperlukan untuk mendukung Moda kegagalan yang dilakukan yaitu:

> Perhitungan Modulus Penampang FSO pada Midship

$>\quad$ Menghitung Tangangan FSO Akibat gaya Gelombang dan air tenang

$>$ Menghitung Tegangan pada Pelat bawah bagian Midship

2. Menetapkan Ambang Batas Keselamatan

Menetapkan ambang batas keselamatan, SM (Safety Margin) yang akan ditinjau atau bisa juga dikatakan sebagai penetapan moda kegagalan (M). Untuk tugas akhir ini ditinjau moda kegagalan kekuatan maksimum memanjang (Longitudinal Ultimate Strength). Moda kegagalan Ultimate Strength, diformulasikan sebagai berikut :

$$
\sigma=\sigma_{\text {plat }}-\left(\sigma_{\mathrm{sw}}+\sigma_{\mathrm{w}}+\sigma_{\mathrm{p}}\right)
$$

Di mana $\sigma_{\text {plat }}$ adalah kapasitas tekuk pelat maksimum, $\sigma_{s w}$ adalah tegangan di air tenang, $\sigma_{\mathrm{w}}$ adalah tegangan di air bergelombang untuk kondisi hagging maupun sagging dan $\sigma_{p}$ adalah tegangan yang diakibatkan oleh tekanan air pada pernukaan pelat pada dasar FSO.

3. Penentuan Dan Karakterisasi Perubah-Perubah Dasar

Penentuan dan karakterisasi perubah-perubah dasar (Basic Variabel, i.e random variabel) untuk selanjutnya dilakukan : 
> Mentransformasikan distribusi fungsi kerapatan peluangnya (pdf. Probability Density Function) fungsi kerapatan kumulatif (cdf. Cummulative Density Function)

$>$ Menentukan harga rata-rata (Mean)

$>\quad$ Koefisien Variasi (cov. Coefficient of Variation)

4. Pemfokusan Hasil Simulasi Monte Carlo

Yang menjadi perhatian adalah bagaimana banyaknya simulasi yang dilakukan benar-benar akan menhasilkan nilai dengan tingkat fariasi yang kecil. Hal ini menjadi penting artinya karena banyaknya jumlah (n) simulasi yang dilakukan akan berpengaruh pada konsistensi nilai yang didapatkan.

Fenomena ini dapat lebih jelas dengan melihat grafik dibawah ini.

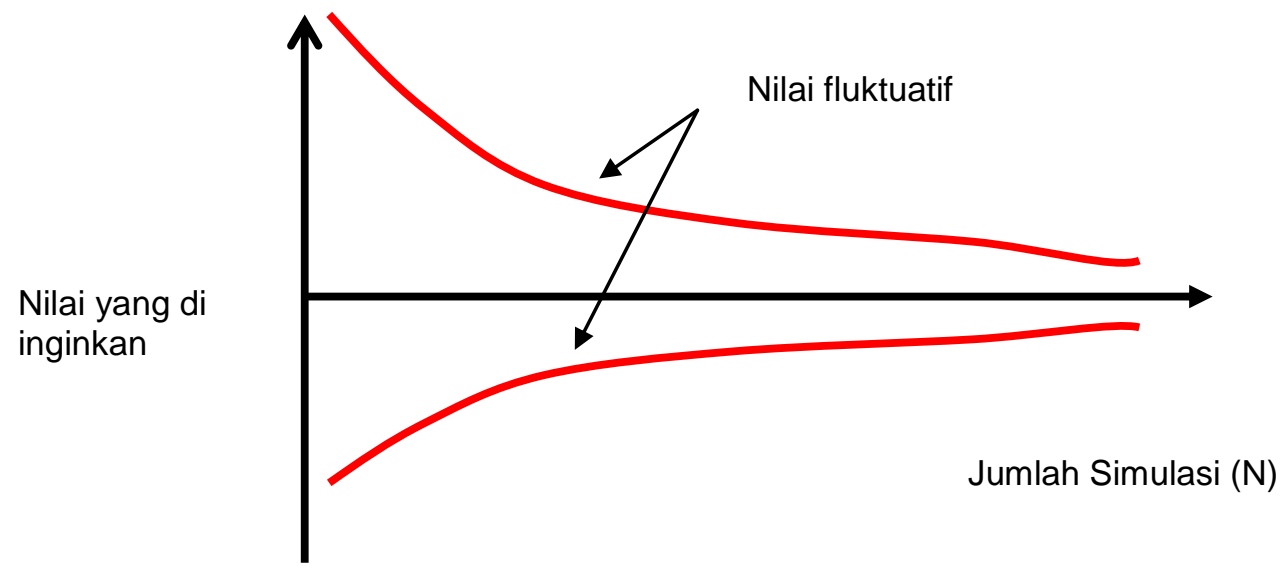

Grafik 6:: Penentuan Jumlah (n) Simulasi

Dengan makin banyaknya jumlah simulasi yang dilakukan, maka hasil yang akan diperoleh akan semakin terfokus pada satu nilai. Julah simulasi yang dilakukan sangatlah bepengaruh pada kompleksitas persamaan yang ada, semakin kompleks maka semakin banya jumlah simulasi yang diperlukan untuk mencapai nilai yang diinginkan.

Adapun Metodologi yang digunakan pada penelitian ini dapat dilihat pada Floechat berkut:

MENARA, JURNAL TEKNIK SIPIL VOL. I, NO. 1, JANUARI 2006: 6-18 


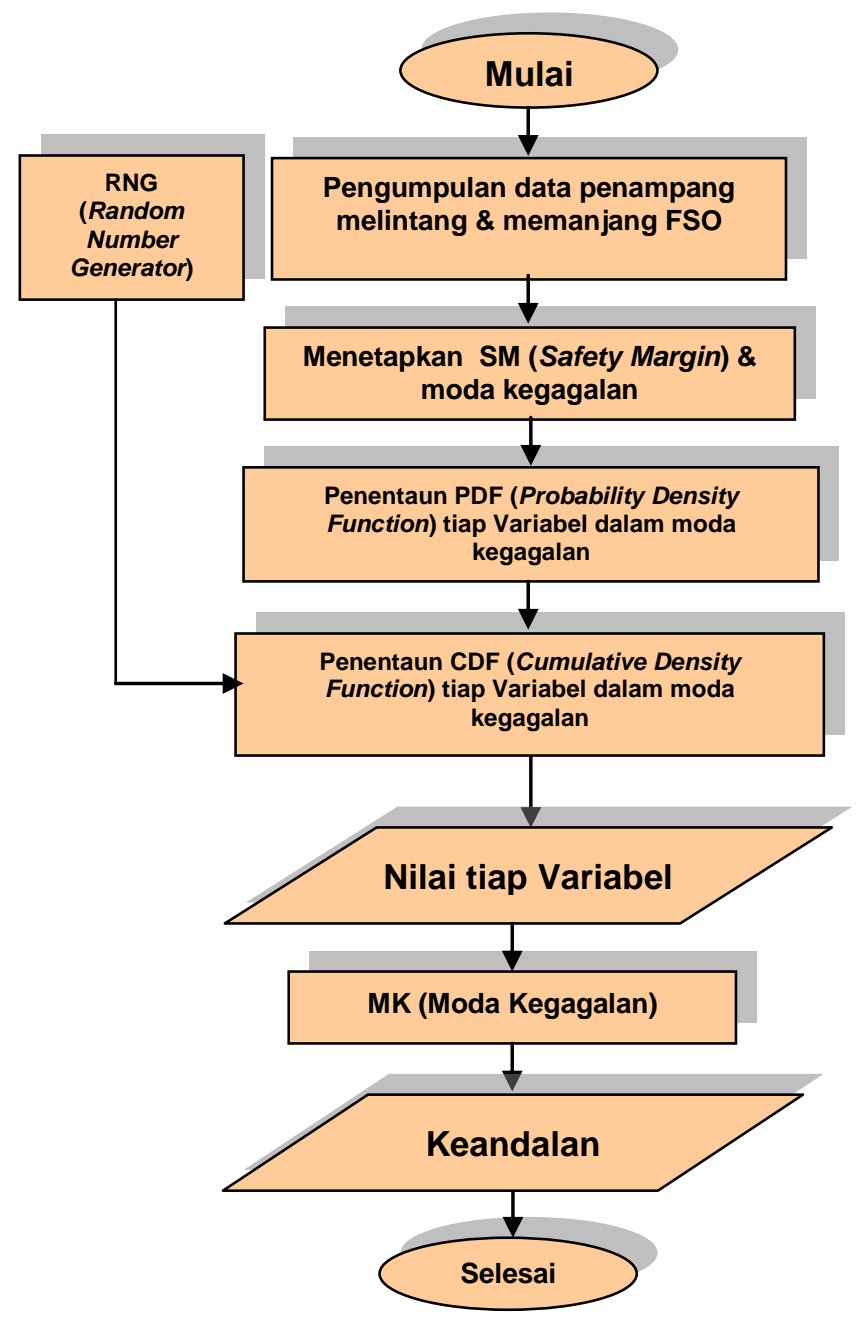

Gambar 7: Metodologi Analisis Keandalan

\section{Kesimpulan Dan Saran}

Adapun kesimpulan dan penulisan ini adalah:

1. Penggunaan analisis keandalan pada struktur FSO sangat memungkinkan untuk dilakukan tentunta dengan data-data yang dipersiapkan terlebih dahulu.

2. Secara garis besar metodologi yang digunakan yaitu mengumpulkan data, menetapkan ambang batas keselamatan, menentukan karasteristik peubah dasar, dan kemudian melakukan simulasi Monte Carlo

\footnotetext{
Aplikasi Analisis Keandalan Pada Kekuatan Pelat Floating Storage Offloading (FSO) Dengan Memakai Simulasi Monte Carlo (Vivian Karim Ladesi, Dosen Jurusan Teknik Sipil FT-UNJ)
} 
3. Disarankan analisis keandalan dapat dilakukan pada tahap perancangan/ perencanaan awal dalam membangun FOS atau kapal yang sejenis.

\section{Daftar Pustaka}

American Bureau of Shipping "Rules for Building and Classing Steel Vessel" 1982.

Friedrich Bleich. "Bickling Strength Of Metal Structures". McGraw-Hill Book Company, 1952.

Hughes, O. "Ship Structural Design : Arationally-based, Computer-Aided, Optimization Approach"; John Wiley and Sons; 1983.

Jeom K. Paik and Alaa E. Mansour "A Simple Formulation for Predicting The Ultimate Strength of Ships", Journal of Marine Science and Technology, 1995.

Jeom K. Paik. "On Advanced Buckling and Ultimate Srange Design of Ship Plating". The Sociciety of Naval Architectc and Marine Engineers, 2000

Lewis, E.V. "Principles of Naval Architecture", Vol 1 : Stability and Strength ; $2^{\text {nd }}$ edition; 1988, SNAME

Mansour, A>E. "An Introduction too the Marine Structure Reliability"; Ship Structure Committee, 1990

Mansour, A.E. ,and Hovern, L. "Probability-based Ship Structure Safety Analysis"; Journal of Ships Research, vol.38. No.4, Dec.1984;SNAME

Osborn, m. "Double-Hull Tankers : Are they the Answer ?", Shell Selected Paper, July, 1994.

Popov,E.P “Mechanics Of Materials”. Erlangga, 1996

Rosyid, D.M.\& Setyawan, D. "Kekuatan Struktur Kapal”, Padnya Paramita, 2000

Thoft-Christensen, P., and Murotsu, Y. "Application of Structural System Reliability Theory", Springer Verlag, 1986

Watson,D.G.M. Practical Ship Design. ELSEVIER. 1998.

MENARA, JURNAL TEKNIK SIPIL VOL. I, NO. 1, JANUARI 2006: 6-18 